\title{
ANALISIS FAKTOR-FAKTOR YANG MEMPENGARUHI KEPATUHAN \\ WAJIB PAJAK DALAM MEMBAYAR PAJAK BUMI DAN BANGUNAN DI TIGA DESA DI KECAMATAN SURALAGA KABUPATEN LOMBOK TIMUR TAHUN 2019
}

\author{
Muhamad Karyadi \\ Universitas Gunung Rinjani \\ Email: muhamadkaryadi01@gmail.com
}

\begin{abstract}
ABSTRAK
Tujuan penelitian ini untuk mengetahui pendapatan, pelayanan pajak, pengetahuan perpajakan, dan penegakan hukum pajak berpengaruh terhadap kepatuhan wajib pajak. Populasi dalam penelitian ini adalah semua wajib pajak bumi dan bangunan di Kecamatan Suralaga (Desa Tebaban, Desa Paok Lombok, dan Desa Dasan Borok) pada tahun 2019 berjumlah 3.391 orang dan menggunakan rumus slovin dalam penerikan sampel. Teknik pengambilan sampel menggunakan teknik cluster proporsional random sampling dan sampel dalam penelitian ini adalah 357 responden. Metode analisis data dengan menggunakan model analisis regresi linier berganda. Hasil dari penelitian ini dapat disimpulkan pendapatan tidak berpengaruh secara parsial dan signifikan terhadap kepatuhan wajib pajak karna nilai $\mathrm{t}$ hitung lebih kecil dari $t$ tabel $(-0,792<1.65251)$ dan nilai signifikansi lebih besar dari $0,05(0,425>0,05)$, pelayanan pajak berpengaruh terhadap kepatuhan wajib pajak karna nilai t hitung lebih besar dari t tabel $(2.364>1.65251)$ dan nilai signifikansi lebih kecil dari $0,05(0,019<0,05)$, pengetahuan perpajakan berpengaruh secara parsial dan signifikan terhadap kepatuhan wajib pajak karna nilai t hitung lebih besar dari t tabel $(1.839<1.65251)$ dan tingkat signifikansi lebih besar dari $0,05(0,067>0,05)$, penegakan hukum pajak tidak berpengaruh secara parsial dan signifikan terhadap kepatuhan wajib pajak karna nilai $\mathrm{t}$ hitung lebih kecil dari $t$ tabel $(0,577<1.65251)$ dan tingkat signifikansi lebih besar dari $0,05(0,564>0,05)$, hasil analisis statistik determinasi diperoleh $R^{2}$ square sebesar 0,039 mengandung arti bahwa pengaruh pariabel independen terhadap variabel devenden adalah $39 \%$.
\end{abstract}

Kata Kunci: Pendapatan, Pelayanan Pajak, Pengetahuan Perpajakan, Penegakan Hukum Pajak, Kepatuhan Wajib Pajak.

\begin{abstract}
The purpose of this study was to determine income, tax services, knowledge of taxation, and tax law enforcement affect taxpayer compliance. The population in this study were all land and building taxpayers in Suralaga District (Tebaban Village, Paok Lombok Village, and Dasan Borok Village) in 2019 totaling 3,391 people and using the slovin formula in sampling. The sampling technique used cluster proportional random sampling technique and the sample in this study was 357 respondents. Data analysis method using multiple linear regression analysis model. The results of this study can be concluded that income does not have a partial and significant effect on taxpayer compliance because the t-count value is smaller than ttable $(-0.792<1.65251)$ and the significance value is greater than $0.05(0.425>0.05)$, service Taxes have an effect on taxpayer compliance because the t-count value is greater than t-table $(2.364>1.65251)$ and the significance value is less than $0.05(0.019<0.05)$, knowledge of taxation has a partial and significant effect on taxpayer compliance because the value $t$ count is greater than $t$ table $(1.839<1.65251)$ and the significance level is greater than $0.05(0.067>0.05)$, tax law enforcement has no partial and significant effect on taxpayer compliance because the $t$-count value is smaller than $t$ table $(0.577<1.65251)$ and the significance level is greater than $0.05(0.564>0.05)$, the results of the statistical analysis of determination obtained $\mathrm{R}^{\wedge} 2$ square of 0.039 , which means that the effect of the independent variable den to the dividend variable is $39 \%$.
\end{abstract}

Keywords: Income, Tax Services, Tax Knowledge, Tax Law Enforcement, Taxpayer Compliance. 


\section{PENDAHULUAN}

Negara Indonesia dalam melancarkan aktivitas pengembangan tentunya membutuhkan biaya salah satunya adalah pajak. Pajak merupakan salah satu sumbangan pungutan dana yang diperlukan untuk membiayai pembangunan, karena pajak diyakini sebagai salah satu tumpuan terbesar pembangunan. Oleh karena itu, diperlukan antusias dari warga negara seperti wajib pajak untuk turut memberikan sumbangan kepada pemerintah melalui pajak dalam rangka ikut membantu pembiayan pembangunan. Sehingga semua kegiatan pembangunan bisa berjalan dengan lancar dalam Faizah (2009:1).

Pajak merupakan pungutan/iuran wajib pajakuntuk Negara berlandaskan undang-undang. Rakyat yang melunasi pajak tidak akan membalas jasa atau memperoleh manfaat secara langsung untuk dirinya sendiri karena pajak dipakai untuk kebutuhan orang banyakdalam (Ayu, 2019).

Berdasarkan pasal 1 UU NO. 28 tahun 2007 mengenai keputusan norma dan prosedur perpajakan. Pajak merupakan pemberian wajibterutang oleh badanatau seseorang kepada negara yang sifatnya tekanan menurut undangundang dengan tidak memperoleh balasan secara spontan dan dipergunakan untuk kebutuhan Negara untuk sebesar-besarnya kemakmuran masyarakat dalam (Ayu, 2019).

Sedangkan menurut Saemitro pajak merupakan sumbangan yang diberikan masyarakat sebagai tabungan Negara (yang diharuskan) dengan tidak adanya balasan (kontraprestasi) yang sepontan dapat diperlihatkan dan dipakai untuk kepentingan umum dalam (Ayu, 2019).

"Undang-undang No.12 tahun 1985 sebagaimana sudah dirubah dengan undang-undang No.12 tahun 1994 tentang pajak bumi dan bangunan, Pajak bumi dan bangunan adalah pajak yang dikenakan atas objek pajak bumi dan bangunan yang diatur dalam undang-undang" (Tjahjono dan Wahyudi, 2005: 345) dalam Faizah (2009).

Dalam pemungutan pajak dibutuhkan ketaatan yang tinggi dari rakyat, ketaatan wajib pajak yaitu suatu keadaan dimana wajib pajak melakukan hak perpajakanya dan mencukupi semua beban pajaknya. Namun dalam kenyataannya salah satu bentuk pajak yang negara sering kesulitan dalam pemungutanya adalah Pajak Bumi dan Bangunan (PBB) dalam Faizah (2009:1). Berdasarkan Menteri Keuangan Indrawati (Depkominfo, 23 November 2006) dalam Faizah (2009:1) kepercayaan masyarakat kepada administrasi pengelolaan pajak dan masih kurangnya tingkat ketaatan wajib pajak adalah salah satu kendala dalam menerapkan optimalisasi perpajakan.

Soekanto dalam Nasucha (2004:132) menyebutkan dasar-dasar kepatuhan membayar pajak yakni orang yang mentaati hukum karena diindoktrinasi untuk mengerjakan seperi yang di kehendaki oleh peraturan hukum tersebut.

Devano dan Rahayu (2006:112) dalam Faizah (2009:5) menyebutkan ada beberapa aspek yang mempengaruhi ketaatan wajib pajak yakni prihal bentuk administrasi, layanan pada wajib pajak, biaya pajak dan pengawasan pajak pendapatan, pengetahuan, penegakan sanksi perpajakan. Disamping itu, yang menyangkut metode pemungutan kepatuhan dan kesadaran memenuhi beban perpajakanya tidak sekedar terkait pada masalah teknis. Penyidikan, penerapan sanksi, teknis pemeriksaan biaya pajak berdasarkan Devano dan Rahayu (2006: 112) ketaatan wajib pajak dan pelayanan kepada wajib pajak mematuhi aturan undang-undangan pajak bergantung dari kemauaan wajib pajak sampai sejauh mana mereka mematuhinya.

Dari sebagian komponen yang mengakibatkan ketaatan wajib pajak dalam melunasi pajak pengkaji hanya mengambil empat faktor yakni pendapatan, pelayanan perpajakan, pengetahuan perpajakan dan penegakan hukum pajak alasanya karena keterbatasan waktu, dana, tenaga dan masih banyak lagi.

Dalam pengertian luas pendapatan merupakan hasil dari pekerjaan. Budiomo (1992: 180) dalam Ananda (2015: 56) menyatakan bahwa pendapatan merupakan produk dari pemasaran aspek-aspek produk yang dimilikinya ke sektor publik. Elisyah (2014) dalam Ananda (2015: 57) menyatakan pendapatan adalah jumlah dari penghasilan (kas dan bukan kas) orang atau satu keluarga selama priode tertentu (Raharja dan Manurung, 2006: 292) dalam Ananda (2015: 57) pendapatan berupa uang biasanya sebagai balas jasa yang diterima dari penghasilan, sumber utama upah ataugaji serta 
timbal balik lainya, seperti dari atasan, dari pekerjaan bebas, pendapatan bersil dari bisnis pribadi, dan pendapatan dari penjualan barang yang dipelihara dari halaman rumah, jaminan sosial, uang pensiun, hasil investasi seperti modal tanah, serta manfaat sosial berbentuk benda adalah semua imbalan yang diperoleh dalam bentuk barang dan jasa.

Pada umumnya kebutuhan untuk diri sendiri akan diprioritaskan oleh masyarakat jika dihadapkan dengan kebutuhan negara seperti membayar pajak .orang yang bekerja lalu mendapatkan upah secara naluriah akan menggunakan pendapatannya untuk mencukupi kepentingan keluarga dan dirinya sendiri. Elisyah (2014) dalam Ananda (2015: 58)

Fraternesi (2002) dalam Ananda (2015: 58) dalam penelitianya telah menunjukkan bahwa factor ketaatan wajib pajak dalam melunasi pajak mempengaruhi kualitas pendapatan. Karna pada saat melunasi pajak bumi dan bangunan ketaatanwajib pajak dipengaruhi oleh besar kecilnya pendapatan, Hal itu berlaku atas apa yang dibayar dari wajib pajak akan pajak bumi dan bangunan berasal dari pendapatan wajib pajak itu sendiri.

Rakyat yang mempuyai tarap penghasilan rendah akan mengalami problema dalam melunasi pajaknya karena alasan banyaknya kepentingan lain yang wajib diutamakan dibandingkan dengan melunasi kewajiban pajaknya, namun berbeda untuk wajib pajak yang mempunyai kualitas penghasilan lebih semestinya tak akan mempunyai problema dalam melunasi pajak $\mathrm{PBB}$ setiap tahunya. Oleh sebab itu, faktor ketaatan wajib pajak pada saat melunasi pajak bumi dan bangunan diduga akan berpengaruh pada pendapatan wajib pajak.

Menurut Santoso (2008) dalam Hasani (2019: 25) menyatakan layanan masyarakat ialah bantuan, baik dari negara, kelompok swasta kepada masyarakat, maupun kelompok swasta atas nama pemerintah, dengan atau tanpa pembayaran guna melengkapi kepentingan dan keperluan sosial.

layanan pegawai pajak adalah pelayanan perolehan dari pegawai pajak kepada rakyat dalam pajak. Instansi pajak yang menyampaikan layanan untuk wajib pajak wajib berbicara dengan sopan, berperilaku komunikatif, paham dengan klien, serta menyampaikan layanan yang simpatik dan menyampaikan rasa nyaman supaya wajib pajak merasa aman dalam melunasi pajak. Hasani (2019: 42)

Petugas pajak bisa dipercaya, terbuka, menyampaikan penjelasan dengan jelas, benar dan waktu yang tepat, pelayanan seperti ini membuat masyarakat aman dan tenang dalam melunasi pajaknya dikantor pelayanan pajak. Hasani (2019: 42)

Secara linguistik, satisfaction bersumber dari bahasa latin yaitu satis yang artinya layak dan facere melakukan atau melaksanakan. Berdasarkan pendekatan linguistic ini maka kepuasan artinya bahwa hasil atau jasa yang bisa memberi lebih dari apa yang diharapkan konsumen. Kepuasan konsumen adalah keadan dimana apa yang diharapkan konsumen bisa terpenuhi (Kotler dan Armstrong: 1999) dalam Manullang (2008: 32).

Mutu pelayanan bisa diartikan menjadi kesetaraan antarakulitas pelayanan yang diharapkan pemakai dengan layanan yang dirasakan pemakai dalam (Sapriadi, 2013). Pelayanan dikatakan berkualitas dan memuaskan Jika kualitas yang di rasakan melebihi kualitas yang diharapkan, begitu juga sebaliknya. Pelayanan mengarah pada harapan masyarakat, lebih praktis, efektif dan bertanggung jawab adalah pelayanan publik yang berkualitas dalam (Hestanto, 2018).

Menurut (Prasuraman, 1985 dalam Sapriadi, 2013) menyebutkan ada 5ukuran karakter layanan yaitu: (Hestanto, 2018)

1. Jaminan (Assurance)

2. Keandalan (Realibility)

3. Emphaty (empati)

4. Daya tangkap (Responsiveness)

5. Bukti fisik (Tangibles)

Berdasarkan kamus besar bahasa Indonesia (2008: 1.377) dalam Adi $(2018,29)$ "pengetahuan berarti segala sesuatu yang diketahui kepandaian atau segala sesuatu yang diketahui berkenaan dengan hal (mata pelajaran)". Menurut Kusrini 
(2006: 23) dalam Adi (2018: 30) "pengetahuan bisa diklasifiksikan menjadi 3 yaknitacit knowledge (pengetahuan tecit), declarative knowledge (pengetahuan deklaratif), dan procedural knowledge (pengetahuan prosedural).

Pengertian pajak merupakan penjelasan pajak yang bisa dipakai oleh wajib pajak sebagai awal untuk menarik kesimpulan, berbuat, dan untuk menuntut aspek atau rencana yang spesipik, yang kaitannya dengan melaksanaan kewajiban dan haknya dibidang perpajakan (Carolina, V, 2007: 7) dalam Adi (2018: 32) "pengetahuan pajak digunakan oleh wajib pajak untuk mengambil keputusan dalam mengambil strategi untuk melaksanakan hak dan kewajiban dibidang perpajakan."

Pengetahuan pajak digunakan oleh wajib pajak untuk menarik ketetapandan rencana dalam melangsungkan kewajiban dan haknya dibidang perpajakan dalam Adi (2018: 46).

Berdasarkan persepsi pemahaman atau pengetahuan pajak Rahayu (2010: 141) dalam Adi (2018: 46) menyatakan pengetahuan tentang kepastian umum dan prosedur perpajakan,manfaat perpajakan, dan prosedur perpajakan di Indonesia harus dimiliki wajib pajak.

Hukum perpajakan merupakan tanggungan bahwa kepastian aturan undang-undang perpajakan akan dipatuhi, ditaati, dan dituruti, dengan kata lain hukum perpajakan yaitu cara untuk mencegah agar wajib pajak tidak melanggar aturan perpajakan Mardiasmo (2009: 57) dalam Adinata (2015: 7).

Penelitian yang dilakukan oleh Jatmiko (2006) dan Yadyana (2009) dalam Adinata (2015: 7) yang menyebutkan bahwa sanksi pajak yang diberikan berpengaruh kepada kepatuhan wajib pajak. Sedangkan penelitian yang dilakukan oleh Chotimah (2007) dalam Adinata (2015: 7) mengambil kesimpulan bahwa sanksi pajak tidak berngaruh terhadap kepatuhan wajib pajak.

Tingkat ketaatan wajib pajak dalam melunasi pajaknya diduga akan berpengaruh kepada Sanksi pajak dikarena semakin keras atau tegasnya hukuman, maka semakin rugi wajib pajak dalam Adinata (2015: 7).

Faktor yang membuat seseorang tidak patuh membayar pajak adalah ketakutan terhadap akibat dari ketidak patuhan, adanya hambatan teknik dalam melaksanaan kewajiban perpajakan, kurangnya penjelasan, rasa ketidak adilan dan harapan dalam (Rakhmad, 2015).

Kehawatiran akan pajak yang dibayar nantinya diselewengkan menjadi pemicu wajib pajak tidak melunasi beban pajak. wajib pajak juga malas untuk mendaftar karena takut dengan dikenakanya hukuman sehingga mereka beranggapan sebaiknya tidak mendaftar dari pada sesudah mendaftar dijatuhi hukuman. Hambatan teknis yang dirasakan oleh wajib pajak yakni proses pelaksanaan kewajiban perpajakan dianggap sulit dari segi hambatan teknis karna wajib pajak merasa akses terhadap pelayanan perpajakan yang tidak memuaskan seperti tempat tinggal wajib pajak tidak dekat dari pelayanan, kurangnya pengetahuan wajib pajak kalau harus mendaftar dan mempunyai NPWP. Jikapun tahu harus mempunyai NPWP, wajib pajak tidak mengerti cara mendaftar NPWP. Rasa ketidak adilan dan keinginan, mereka merasa teraniaya karna pajak yang dilunasi tidak diolah dengan baik dalam (Rakhmad, 2015)

Menurut Yusnindar (2015:3) dalam (Asriyani, 2014) ketaatan wajib pajak diakibatkan oleh beberapa faktor yakni.

1) Pengetahuan wajib pajak

Rancangan pengetahuan pajak yakni wajib pajak harus mencakup pengetahuan mengenai prosedur pajak di Indonesia, pengetahuan mengenai manfaat pajakdan kemampuan mengenai ketentuan umum perpajakan. (Asriyani, 2014)

2) Tingkat penghasilan

Salah satu hal yang dipertimbangkan saat penarikan pajak yakni jumlah pendapatan, karenajumlah pendapatan akan mempengaruhi kepatuhan wajib pajak pada saat melunasi pajak tepat waktu. Wajib pajak berupaya untuk melunasi kewajiban pajak berhubungan erat denganpenghasilan. (Asriyani,2014)

3) Kesadaran wajib pajak

Kesadaran wajib pajak dalam melunasi beban pajak akan bertambah apabila dalam 
diri mereka ada anggapan baik tehadap pajak. kesadaran wajib pajak untuk melunasi beban pajaknyadiakibatkan oleh bertambahnya pengetahuan perpajakan merek dengan pengetahuan perpajakan baik pendidikan langsung maupun tidak langsung. Karakterwajib pajak yang diperlihatkan oleh keadaan budaya, kemasyarakatan dan ekonomi akan mengacu pada prilaku wajib pajak yang terlihat dalam kesadaran mereka melunasi pajaknya. Dengan melakukan sosialisasi perpajakan secara langsung akan menambah pengertian wajib pajak mengenai kewajiban melunasi pajaknya sebagai wujud kebersamaan dalam negari untuk mengumpulkan dana demi kepentingan pembiyayaan pemerintahan dan pengembangan dalam negeri. (Asriyani, 2014)

4) Pemahaman wajib pajak terhadap hukum

Sanksi yang diberikan pada wajib pajak yang tidak patuh terhadapperintah pajak atau pelanggaran perintah perpajakan seperti kecurangan kepada peraturan perpajakan yang ada saat ini. Sanksi pajak yaitu suatu perspektif yang mengakibatkan wajib pajak patuh, dikarenakanmanfaat sanksi yakni dipakai untuk mengatur krumunan masyarakat agar mematuhi peraturan yang sudah ada. ditegakannya sanksi seperti denda ataupun penjara yang sangat berat tujuan wajib pajak akan taat dalam hal melunasi PBB.Sanksi perpajakan diterapkan karena didapatkan pelanggaran kepada peraturan hukum perpajakan. tatkala ditemukan pelanggaran maka wajib pajak dijatuhi hukuman berdasarkan peraturan perpajakan. diperaturan perpajakan terdapat 2 jenis sanksi, yakni hukum administrasi dan hukum pidana.sanksi administrasi diberikan untuk mereka yang tidak mematuhi norma perpajakan atau membuat pelanggaran kepada norma pajak yang ada,sanksi adminstrasi seperti pembayaran kerugian pada Negara bisa berupa bunga, kenaikan, atau denda. (Asriyani, 2014)

5) Kualitas pelayanan
Menurut keputusan Mentri Pendayagunaan Aparatur Negara 63/KEP/M.PAN/7/2003 tentang panduan mewujutkan pelayanan masyarakat, mewajibkan setiap pemrograman pelayanan masyarakat mempunyai batasan pelayanan yang disebarkan sebagai tanggungan adanya kejelasan bagi penerima pelayanan seperti pelayanan perpajakan. (Asriyani, 2014)

\section{METODOLOGI PENELITIAN}

Jenis penelitian yang dipakai dalam penelitian ini ialah penelitian kuantitatif. Penelitian kuantitatif merupakan penelitian rasional yang logis dan menekankan pada keadaan serta kaitannya yang objektif dan dikaji secara kuantitatif artinya menggunakan konsep-konsep dan asumsi yang kaitanya dengan keadaan alam.Penelitian ini ialah penelitian asosiatif dengan bentuk kaitan kausal. Menurut Sugiyono (2014: 37) hubungan kausal adalah hubungan yang sifatnya sebab akibat.

\section{Tempat Penelitian}

Penelitian ini dilaksanakan di Desa Tebaban, Desa Paok Lombok dan Desa Dasan Borok Kecamatan Suralaga, dilanjutkan analisis data dan kategorisasi keterangan penelitian.

\section{Populasi Dan Sampel Penelitian}

\section{a. Populasi Penelitian}

Populasi adalah segala yang ada di wilayah penelitian yang terdiri dari: pokok/penomena yang mempunyai mutu atau karakteristik khusus yang diputuskan oleh peneliti untuk diteliti dan selanjutnya di tarik kesimpulanya (Sugiyono, 2014:80). Dalam penelitian ini populasi ialah semua wajib pajak bumi dan bangunan yang ada di Kecamatan Suralaga tempatnya di Desa Tebaban, Desa Dasan Borok dan Desa Paok Lombok.

Berdasarkan data yang ada, wajib pajak bumi dan bangunan tahun 2019 di Desa Tebaban sebanyak 1.523 orang, Desa Dasan Borok sebanyak 559 orang dan di Desa Paok Lombok sebanyak 1.309 orang. pegawai pajak yang memungut $\mathrm{PBB}$ yang ada di Kecamatan Suralaga. Pada Table 3.6 
berikut ini bisa dilihat desa dan wajib pajak yang menjadi populasi dalam penelitian ini.

Table 3.1

Populasi wajib pajak tahun 2019

\begin{tabular}{|c|l|c|}
\hline No & \multicolumn{1}{|c|}{ Desa } & Populasi WP \\
\hline 1 & Tebaban & 1.523 \\
\hline 2 & Dasan Borok & 559 \\
\hline 3 & Paok Lombok & 1.309 \\
\hline & Total & 3.391 \\
\hline
\end{tabular}

Sumber: data diolah

\section{b. Sampel Penelitian}

Sampel ialah sebagian dari semua atau seluruh total yang dipunyai oleh populasi tersebut (Sugiyono, 2014:81). Dari pengertian tersebut dapat didefinisikan bahwa sampel merupakan bagian dari populasi yang karakteristiknya akan diteliti, dan dapat mewakilkan semua populasinya sehingga banyaknya lebih kecil dari populasi.

Dalam penelitian ini peneliti memakai rumus slovin dalam pengambilan sampel karena jumlahnya harus representative agar hasilnya bisa diperhitungkan berdasarkan jumlah sampelnya. Dalam penelitian ini peneliti mengambil Sampel di tiga desa untuk menghemat waktu tenaga dan biaya yaitu di Desa Tebaban, Desa Dasan Borokdan Desa Paok Lombok. Standar sampel dengan Rumus Slovin dalam Husein (2005:108) dalam Faizah (2009:46) :

Dimana :

$$
n \frac{N}{1+N e^{2}}
$$

$\mathrm{n}=$ Ukuran sampel/jumlah responden

$\mathrm{N}=$ Ukuran populasi

$\mathrm{E}=$ Presentase kelonggaran ketidaktelitian karena kesalahan pengambilan sampel yang masih bisa ditoleriratau diinginkan misalnya untuk penelitian ini menggunakan 5\%

Dengan jumlah populas 3.391 orang maka batas minimal pengambilan sampel berdasarkan rumus diatas adalah:

$$
\begin{aligned}
& n=\frac{3.391}{1+3.391(0,05)^{2}} \\
& n=\frac{3.391}{1+8.477} \\
& \mathrm{n}=\frac{3.391}{9,477} \\
& \mathrm{n}=357
\end{aligned}
$$

Maka sampel pada penelitian ini ialah357 orang wajib pajak bumi dan bangunan yang ada di Desa Tebaban, Dasan Borokdan Paok Lombok Kecamatan Suralaga.

Penelitian ini memakai teknik cluster proportional random sampling untuk mendapatkan sampel. teknik ini merupakan teknik pengambilan sampel diambil secara acak bersumber pada kategori yang di tarik dari tiap sub populasi dengan mempertimbangkan sub-sub populasi, dalam penelitian ini subjek populasinya sangat luas. Oleh sebab itulah peneliti menggunakan teknik tersebut dalam pengambilan sampel.Faizah (2009)

\section{Teknik Pengumpulan Data}

\section{a. Teknik angket (kuesioner)}

Kuisioner adalah data dikumpulkan dengan cara memberikan pernyataan atau pertanyaan tertulis untuk dijawab oleh responden. (Sugiyono, 2014:142). Untuk mengukur konsep dalam penelitian ini memakai alat ukur interval/skala interval yang kemungkinan peneliti untuk mengasih nilai pada setiap jawaban responden. Konsep penelitian ini meliputi konsep pendapatan, pelayanan pajak, penegtahuan perpajakan, dan penegakan hukum pajak. Metode perskalaan dalam penelitian ini menggunakan skala liker 5 poin.

Konsepsi dalam penelitian ini melingkupi konsepsi pendapatan, pelayanan pajak, pengetahuan perpajakan, dan penegakan hukum pajak menjadi variabel inevendenden. Sedangkan variabel 
dependennya yakni kepatuhan wajib pajak bumi dan bangunan. Konsepsi-konsepsi tersebut dilihat dengan menggunakan pengukuran interval/skala interval yang digunakan peneliti sebagai pemberikan nilai untuk setiap jawaban responden. Sedangkan teknik perskalaan yang dipakai dalam penelitian ini adalah skala liker 5 poin.

\section{b. Instrumen Penelitian}

Angket atau kuisioner merupakan alat yang dipakai dalam penelitian yang berisi permasalahan untuk mendapatkan informasi dari variabel yang akan diteliti. Dalam penelitian ini responden menjawab pertanyaan dalam bentuk checklist $(\sqrt{ })$ yang sudah disediakan. Hasani (2019: 36). Skor yang dipakai dalam penelitian ini menggunakan skala liker 5 poin. Skala liker adalah jawaban mengenai kesetujuan responden terhadap statemen atau pernyataan yang dinyatakan melampaui opsi jawaban yang disiapkan. Menurut Hadi (1991: 19) dalam Hasani (2019: 36)

Menggunakan skala liker untuk memperkirakan prilaku, pendapatan, dan tanggapan seseorang tentang kejadian sosial Sugiyono (2014: 93). Dalam penelitian, kejadian sosial telah ditetapkan secara spesifik oleh peneliti, yang kemudian disebut sebagai variabel penelitian. Variabel diukur dengan menggunakan skala liker yang kemudian diperjelas menjadi indikator variabel kemudian indikator tersebut dijadikan sebagai titik total untuk menyusun item-item yang bisa berupa pentanyaan atau pernyataan.Sugiyono (2014: 93). Skala liker mempunyai gradasi jawaban dari setiap item istrumen yang digunakan dari sangat positif sampai sangat negatif yang bisa berupa kata-kata antara lain:Sugiyono (2014: 93)

Diberi skor ( 5) dengan kategori sangat setuju/selalu/sangat positif,diberi skor (4) dengan kategori setuju/sering/ positif, diberi skor (3) dengan kategor raguragu/kadang-kadang/netral, diberi skor (2) dengan kategori tidak setuju/hampir tidak pernah/negative, diberi skor (1) dengan kategori sangat tidak setuju/tidak setuju. Sugiyono (2014:94)

Maka dalam penelitian ini dengan memakai lima alternatif jawaban yaitu: sangat setuju (SS), setuju (ST), ragu-ragu (RG), tidak setuju (TS), sangat tidak setuju (STS). Sugiyono (2014: 94)

Tipe angket yang dipakai dalam penelitian ini yakni tipe angket pilihan yang meminta responden untuk menjawab pertanyaan. Jawaban yang sudah dijawab dalam angket ini diberikan skor. Skor yang diberikan untuk masing-masing pilihan jawaban menggunakan modifikasi skala liker.

Ada 5 kategori jawab responden dalam penelitian ini yaitu sangat setuju (SS), setuju (ST), ragu-ragu (RG), tidak setuju (TS), sangat tidak setuju (STS), dari jawaban tersebut memiliki bobot skor dengan penjelasan sebagai berikut:

Kriteria penilaian dalam angket atau kuesioner ini apabila:

$\begin{array}{ll}\text { SS (sangat setuju) diberi skor } & : 5 \\ \text { ST (setuju) } & : 4 \\ \text { RG (ragu-ragu) } & : 3 \\ \text { TS (Tidak Setuju) } & : 2 \\ \text { STS (sangat tidak setuju) } & : 1\end{array}$

Angket yang di gunakan dalam penelitian ini, yaitu angket pengembangan yang dilakukan oleh Faizah (2009) dan Khoiroh (2017)

\section{HASIL PENELITIAN DAN PEMBAHASAN}

Tempat obsservasi ini di Kecamatan Suralaga Kabupaten Lombok Timur, tempatnya ditiga desa yaitu di Desa Tebaban, Desa Paok Lombok, Desa Dasan Borok. Desa tebaban mempuyai luas wilayah 221,00 Ha dan berpenduduk 5.398 jiwa, Desa Paok Lombok mempuyai luas wilayah 235,866 Ha dan berpenduduk 3.433 jiwa, dan Desa Dasan Borok mempunyaii luas wilayah 169,25 Ha dan berpenduduk 2.250 jiwa. 


\section{Cara Pembayaran PBB}

Pelunasan PBB Di Desa Tebaban, Desa Paok Lombok, dan Desa Dasan Borok Kecamatan Suralaga Kabupaten Lombok Timur dilunasi secara individu dimana surat pemberian pajak terutang (SPPT) diberikan langsung kepada pegawai pajak yang memungut pajak bumi dan bangunan di Kecamatan Suralaga kepada para wajib pajak. Sehabis wajib pajak menerima (SPPT), wajib pajak dapat melunasi PBBnya secara langsung kepada pegawai pajak.

\section{Jumlah Wajib Pajak}

Jumlah wajib pajak PBB tahun 2019 di Desa Tebaban berjumlah 1.523 orang. Wajib pajak ini dibagi dalam 4 kekadusan yaitu Tebaban Barat, Tebaban Daya, Tebaban Timur, Tebaban Saung. Di bagi dalam 19 Rukun Tetangga (RT) dengan berbagai pekerjaan. Sedangkan wajib pajak bumi dan bangunan di Desa Paok Lombok berjumlah 1.309 orang. Wajib pajak ini terbagi dalam 5 kekadusan yaitu Dusun Paok Lombok Timur, Dusun Paok Lombok Barat, Dusun Paok Lombok Utara, Dusun Kopong, Dusun Getap terbagi menjadi 16 Rukun Tetangga (RT). Kemudian wajib pajak bumi dan bangunan di Desa Dasan Borok berjumlah 559 orang. Wajib pajak ini terbagi dalam 4 kekadusan yaitu Dusun Dasan Borok, Dusun Darul Muttakin, Dusun Kaliancar, Dusun Sari indah terbagi menjadi 8 Rukun Tetangga (RT) denagn mata pencaharian yang bermacammacam .

Data observasi ini dikumpulkan dengan mengedarkan 357 kuisioner secara langsung pada wajib pajak di Kecamatan Suralaga, tepatnya di Desa Tebaban, Desa Paok Lombok, dan Desa Dasan Borok waktu observasi dilangsung kurang lebih satu bulan setengah (bulan juni $\mathrm{s} / \mathrm{d}$ bulan juli 2020) dengan mendatangi rumah wajib pajak dan kantor desanya secara langsung untuk meminta data.

Pengambilan data menggunakan penyebaran kuisioner pada awal bulan juni 2020 sampai dengan akhir bulan juni 2020 di Desa Tebaban, Desa Paok Lombok, dan Desa dasan Borok kecamatan suralaga, kuisioner tersebar sebanyak 357 kuisioner dan kuisioner yang lagi terkumpul sebanyak 357, karena semua wajib pajak di Kecamatan Suralaga yang dijadikan sebagai sampel penelitian bersedia mengisi kuisioner penelitian, oleh karena itu tidak ada kuisioner yang gugur.

\section{Analisis Hasil Penelitian}

\section{a. Uji Analisis Regresi Linier Berganda}

Cara yang dipakai pada observasi ini ialah cara/model analisis regresi linier berganda (multiple regression analisys). Regresi linier berganda yaitu untuk mengetahui seberapa besar pengaruh antara satu variabel independen atau bila jumlah variabelnya minimal dua (Sugiyono, 2012: 278) dalam Asgar (2019: 70).

Berdasarkan data yang sudah dikumpulkan, maka diperoleh hasil olahan sebagai berikut.

Rumusnya: $\mathrm{Y}=\mathrm{a}+\mathrm{b} 1 \mathrm{X} 1+\mathrm{b} 2 \mathrm{X} 2+\mathrm{b} 3 \mathrm{X} 3+$ b4X4 + e

$\mathrm{Y}=16,203+(-0,055) \mathrm{X} 1+0.184 \mathrm{X} 2+0,124 \mathrm{X} 3$ $+0,037 \mathrm{X} 4$

Dari hasil uji regresi linier berganda dapat dideskrifsikan sebagai berikut:

\section{Konstanta (a)}

Nilai konstanta yang didapat sebanyak 16,203 . hal ini artinya bahwa apa bila variabel independen pendapatan, pelayanan pajak, pengetahuan perpajakan, penegakan hukum pajak (X1,X2,X3,dan X4) tidak punya atau nilainya nol, maka besarnya kepatuhan wajib pajak (Y) adalah nilai konstanta yang didapat sebesar 16,203.

\section{Koefisien Regresi X1 (Pendapatan)}

Nilai koefisien pendapatan (X1) bernilai negatif sebesar $-0,055$ menunjukkan bahwa setiap pendapatan (X1) sebesar satusatuan maka akan menurunkan kepatuhan wajib pajak sebesar 0,356 dengan asumsi nilai variabel independen lainya konstan.

\section{Koefisien Regresi X2 (Pelayanan Pajak)}

Nilai koefisien pelayanan pajak (X2) bernilai positif 0,184 menunjukkan bahwa setiap pelayanan pajak (X2) sebesar satusatuan maka akan meningkatkan kepatuhan wajib pajak (Y) sebesar 0,184 dengan asumsi 
nilai variabel lainnya konstan.

\section{Koefisien Regresi X3 (Pengetahuan Perpajakan) \\ Nilai koefisien pengetahuan} perpajakan (X3) bernilai positif 0,124 menunjukkan bahwa setiap pengetahuan perpajakan (X3) sebesar satu-satuan maka akan menaikkan kepatuhan wajib pajak sebesar 0,124 dengan asumsi nilai variabel independen lainya konstan.

\section{Koefisien Regresi X4 (Penegakan Hukum} Pajak)

Nilai koefisien penegakan hukum pajak (X4) bernilai positif 0,037 menunjukkan bahwa setiap penegakan hukum pajak (X4) sebesar satu-satuan maka akan menaikan kepatuhan wajib pajak $(\mathrm{Y})$ sebesar 0,037 dengan asumsi nilai variabel lainnya konstan.

\section{c. Uji Parsial (Uji t)}

Uji statistik $\mathrm{t}$ digunakan untuk melihat seberapa besar akibat satu variabel secara individual dalam menjelaskan variasivariabel dependen. Hasil uji statistik sebagai berikut:

Uji t dipakai untuk melihat akibat dari variabel bebas kepada variabel terikat. keputusan kesimpulan diambil berdasarkan nilai $\mathrm{t}$ hitung masing-masing koefisien regresi dengan $t_{\text {tabel }}$ pada signifikansi $5 \%$.

Berdasarkan hitungan regresi pada tabel 1.18 melihatkan bahwa thitung untuk variabel pendapatan dengan ketaatan melunasi pajak berjumlah $-0,792$, variabel pelayanan pajak dengan kepatuhan melunasi pajak berjumlah 2.364, variabel pengetahuan perpajakan dengan ketaatan melunasi pajak pajak 1,839 , variabel penegakan hukum pajak dengan ketaatan melunasi pajak berjumlah 0577, sedangkan $t_{\text {tabel }}$ dengan signifikansi 5\% adalah 1.65251 .

Hipotesis 1 : berdasarkan pendapatan tidak berpengaruh signifikan kepada kepatuhan wajib pajak di Kecamatan Suralaga (Desa Tebaban, Desa Paok Lombok, dan Desa Dasan Borok) dari perhitungan diatas didapat nilai sig $0,429>0,05$ dan $t$ hitung lebih rendah dari t tabel yaitu $-0,792>1.65251$ jadi dapat disimpulkan bahwa jika dilihat dari nilai sig dan $t$ hitung yang lebih kecil dari t tabel maka Ha ditolak dan Ho diterima. Sehingga secara parsial tidak ada pengaruh pendapatan terhadap kepatuhan wajib pajak.

Hipotesis 2 : berdasarkan observasi bahwa pelayanan pajak berpengaruh signifikan terhadap kepatuhan wajib pajak di Kecamatan Suralaga (Desa Tebaban, Desa Paok Lombok, dan Desa Dasan Borok) dari output diatas di peroleh sig $0,019<0,05$ dan $t$ hitung lebih tinggi dari t tabel yaitu $2.364>$ 1.65251 jadi dapat disimpulkan bahwa jika dilihat dari nilai sig dan $t$ hitung yang lebih tinggi dari t tabel maka Ha diterima dan Ho ditolak. Sehingga secara parsial ada pengaruh dari pelayanan pajak terhadap kepatuhan wajib pajak.

Hipotesis 3 : berdasarkan hasil penelitian bahwa pengetahuan perpajakan tidak berpengaruh signifikan terhadap kepatuhan wajib pajak di kecamatan Suralaga (Desa Tebaban, Desa Paok Lombok, dan Desa Dasan Borok) dari output diatas diperoleh nilai sig $0,067>0,05$ dan thitung lebih besar dari $t$ tabel $1,839>1.65251$ jadi bisa diambil kesimpulan bahwa jika dilihat dari nilai sig dan $t$ hitung yang lebih tinggi dari $t$ tabel maka Ha diterima dan Ho ditolak sehingga secara parsial ada pengaruh dari pengetahuan perpajakan terhadap kepatuhan wajib pajak.

Hipotesis 4 : berdasarkan hasil penelitian bahwa penegakan hukum pajak tidak berpengaruh signifikan terhadap kepatuhan wajib pajak di Kecamatan Suralaga (Desa Tebaban, Desa Paok Lombok, dan Desa Dasan Borok) dari output diatas diperoleh sig $0,564>0,05$ dan $\mathrm{t}$ hitung lebih rendah dari $\mathrm{t}$ tabel $0,577<1.65251$ bisa di ambil kesimpulan bahwa jika dilihat dari nilai sig dan $t$ hitung yang lebih kecil dari $t$ tabel maka Ha ditolak dan Ho diterima sehingga secara parsial tidak ada pengaruh dari penegakan hukum pajak terhadap kepatuhan wajib pajak. 


\section{d. Uji Simultan (Uji F)}

Dalam hal ini apakah variabel pendapatan, pelayanan pajak, pengetahuan perpajakan, dan penegakan hukum pajak berpengaruh terhadap kepatuhan wajib pajak secara simultan Uji $F$ atau uji koefisien regresi secara bersama-sama dipakai untuk melihat apakah secara bersamaan variabel independen berpengaruh kepada variabel dependen.. Hasil uji $\mathrm{F}$ dapat dilihat pada tabel berikut ini:

Hipotesis 5 : setelah dilakukanya penelitian bahwa pendapatan, pelayanan pajak, pengetahuan perpajakan, dan penegakan hukum pajak berpengaruh signifikan secara simultan kepada kepatuhan wajib pajak di Kecamatan Suralaga (Desa Tebaban, Desa Paok Lombok, dan Desa Dasan Borok)

Dari output diatas diperoleh sig $0,008<$ 0,05 sehingga Ho ditolak, dengan demikian $\mathrm{Ha}$ diterima. Berdasarkan output diatas dapat ditarik kesimpulan bahwa X1, X2, X3, dan X4 (pendapatan, pelayanan pajak, pengetahuan perpajakan, dan peegakan hukum pajak) secara simultan atau bersama-sama mempunyai pengaruh yang signifikan terhadap Y (kepatuhan wajib pajak).

Dari hasil penjumlahan regresi pada tebel 4.19 di peroleh hasil $\mathrm{F}$ hitung sebanyak 3.540 sedangkan $\mathrm{F}$ tabel sebanyak a 2.41. dari hasil penjumlahan diatas tampak bahwa $\mathrm{F}$ hitung $>\mathrm{F}$ tabel bisa ditarik kesimpulan bahwa pendapatan, pelayanan pajak, pengetahuan perpajakan, penegakan hukum pajak secara simultan atau bersama berpengaruh secara signifikan terhadap kepatuhan wajib pajak bumi dan bangunan di desa tebaban, desa paok lombok, dan desa dasan borok di kecamatan suralaga sehingga Ho ditolak dan Ha diterima.

\section{Pembahasan Hasil Pengujian Hipotesis}

Penelitian ini ditujukan untuk mengetahuai faktor-faktor yang mempengaruhi kepatuhan wajib pajak dalam melunasi pajak bumi dan bangunan di Kecamatan Suralaga (Desa Tebaban, Desa Paok Lombok, dan Desa Dasan Borok). Adapun pembahasan dari hasil pengujian hipotesis tersebut sebagai berikut:

\section{a. Pengaruh Pendapatan terhadap}

\section{Kepatuhan Wajib Pajak}

Berdasarkan hasil kajian statistik diperoleh angka $t$ hitung pendapatan sebesar $-0,792$ dan angka $t$ tabel 1.65251 pada signifikansi 0,429 dapat dinyatakan bahwa pendapatan tidak berpengaruh secara parsial dan signifikan padda kepatuhan wajib pajak, karena angka $\mathrm{t}$ hitung lebih sedikit dari t tabel $(-0,792<$ 1.65251) dan nilai signifikansi lebih kecil dari $0,05(0,429>0,05)$. Berdasarkan hasil uji statistik perbandingan antara $t$ hitung dan $t$ tabel diperoleh kesimpulan $\mathrm{Ho}$ diterima dan $\mathrm{Ha}$ ditolak sehingga secara parsial tidak berpengaruh signifikan antara pendapatan pada kepatuhan wajib pajak.

Hasil penelitian ini sama dengan hasil penelitian yang dilakukan oleh Ananda (2015) yang menyebutkan bahwa berdasarkan nilai signifikansi dengan alpha 0,05 variabel pendapatan mempunyai nilai 0,055 lebih tinggi dari alpha 0,05 sehingga secara parsial variabel pendapatan tidak berpengaruh signifikan terhadap kepatuhan wajib pajak.

b. Pengaruh Pelayanan Pajak Terhadap Kepatuhan Wajib Pajak

Dari hasil analisis statistik diperoleh nilai $t$ hitung pelayanan pajak sebanyak 2.364danjumlah t tabel 1.65251 pada signifikansi 0,019 dapat dinyatakan bahwa pelayanan pajak berpengaruh secara parsial dan signifikan pada kepatuhan wajib pajak, karna jumlah t hitung lebih banyak dari t tabel $(2.364>1.65251)$ dan jumlah signifikansi lebih kecil dari 0,05 $(0,019<0,05)$. Berdasarkan hasil uji statistik kesetaraan antara $\mathrm{t}$ hitung dan $\mathrm{t}$ tabel di peroleh kesimpulan Ho ditolak dan Ha diterima sehingga ada hasil positif dan signifikan antara pelayanan pajak pada kepatuhan wajib pajak.

Hasil penelitian ini sama dengan hasil penelitian yang dilakukan oleh 
Hasani (2019) yang menyaebutkan bahwa secara parsial terdapat pengaruh antara pelayanan pegawai pajak pada kepatuhan wajib pajak. Karna berdasarkan hasil uji statistik yaitu menggambarkan tingkat signifikansi adalah $0,002<0,025$ dan $t$ hitung lebih tinggi dari t tabel yaitu 3.220 $>1.98472$ jadi dapat disimpulkan bahwa jika dilihat dari nilai signifikansi dan $t$ hitung yang lebih tinggi dari t tabel maka Ha diterima dan Ho ditolak.

c. Pengaruh Pengetahuan Perpajakan Terhadap Kepatuhan Wajib Pajak

Dari hasil analisis statistik diperoleh jumlah $\mathrm{t}$ hitung pengetahuan perpajakan sebesar 1,839 dan jumlah $t$ tabel 1.65251 pada signifikansi 0,067 dapat dinyatakan bahwa pengetahuan perpajakan berpengaruh secara parsial dan tidak signifikan pada kepatuhan wajib pajak, karna nilai t hitung lebih tinggi dari $t$ tabel $(1,839<1.65251)$ dan nilai signifikansi lebih besar dari $0,05 \quad(0,067>0,05)$. Berdasarkan hasil uji statistik perbandingan antara $\mathrm{t}$ hitung dan $\mathrm{t}$ tabel diperoleh kesimpulan Ho ditolak dan $\mathrm{Ha}$ diterima sehingga secara parsia berpengaruh signifikan antara pengetahuan perpajakan pada kepatuhan wajib pajak.

Hasil penelitian ini tidak sama dengan hasil penelitian yang dilakukan oleh Adi (2018) yang menyebutkan bahwa pengetahuan perpajakan berpengaruh positif dan signifikan pada kepatuhan wajib pajak, nilai koefesien regresi yang positif yaitu sebanyak 1.051 jumlah $t$ hitung yang lebih tinggi dari t tabel yaitu $10.691>4.675$.

d. Pengaruh Penegakan Hukum Pajak Terhadap Kepatuhan Wajib Pajak

Dari hasil analisis statistik diperoleh nilai $\mathrm{t}$ hitung penegakan hukum pajak sebanyak 0,577 dan jumlah t tabel 1.65251 pada signifikansi 0,564 dapat dinyatakan bahwa penegakan hukum pajak tidak berpengaruh secara parsial dan signifikan pada kepatuhan wajib pajak, karna jumlah $t$ hitung lebih rendah dari $t$ tabel $(0,577<1.65251)$ dan nilai signifikansi lebih tinggi dari $0,05(0,564<$ $0,05)$. Berdasarkan hasil uji statistik kesetaraan antara $\mathrm{t}$ hitung dan $\mathrm{t}$ tabel di peroleh kesimpulan $\mathrm{Ha}$ ditolak dan $\mathrm{Ho}$ diterima sehingga tidak berpengaruh secara parsial dan signifikan antara penegakan hukum pajak pada kepatuhan wajib pajak.

Hasil penelitian ini tidak sejalan dengan hasil penelitian yang dilakukan oleh Adinata (2015) yang menyebutkan bahwa variabel sanksi pajak berpengaruh pada kepatuhan wajib pajak, dari hasil uji t didapat $\mathrm{t}$ hitung $>\mathrm{t}$ tabel yaitu $2.363>$ 1.985 dengan jumlah signifikansi sebayak 0.020 dan tingkat kesalahan alpha sebesar 0,05 .

e. Pengaruh Pendapatan, Pelayanan Pajak, Pengetahuan Perpajakan, Dan Penegakan Hukum Pajak Terhadap Kepatuhan Wajib

Berdasarkan hasil analisis statistik didapat jumlah $\mathrm{F}$ hitung sebesar 3.540 dan jumlah $\mathrm{F}$ tabel 2.41, dapat dinyatakan bahwa variabel independen (pendapatan, pelayanan pajak, pengetahuan perpajakan, dan penegakan hukum pajak) berpengaruh secara simultan dan signifikan terhadap variabel dependen (kepatuhan wajib pajak) karna jumlah $\mathrm{F}$ hitung lebih tinggi dari $\mathrm{F}$ tabel $(3.540>2.41)$ dan jumlah signifikansi lebih rendah dari $0,05(0,008<$ $0,05)$. Berdasarkan hasil uji statistik perbandingan antara $\mathrm{F}$ hitung dan $\mathrm{F}$ tabel diperoleh kesimpulan Ha diterima dan Ho ditolak sehingga berpengaruh secara simultan dan signifikan antara X1, X2, X3, dan X4 (pendapatan, pelayanan pajak, pengetahuan perpajakan, dan penegakan hukum pajak) terhadap Y (kepatuhan wajib pajak) 


\section{KESIMPULAN}

Dari hasil observasi dan pembahasan yang sudah dijelaskan diatas maka dalam penelitian ini bisa diambil kesimpulan sebagai berikut:

1) Pendapatan tidak berpengaruh pada kepatuhan wajib pajak di Kecamatan Suralaga (Desa Tebaban, Desa Dasan Borok, dan Desa Paok Lombok). Hal ini ditunjukkan dengan nilai koefesien regresi variabel pendapatan sebesar 0,055 jumlah $\mathrm{t}$ hitung sebayak $-0,792<\mathrm{t}$ tabel 1.65251 dengan tingkat signifikansi $0,0429>$ 0,05 .

2) Pelayanan pajak berpengaruh pada kepatuhan wajib pajak di Kecamatan Suralaga (Desa Tebaban, Desa Dasan Borok, dan Desa Paok Lombok) hal ini dilihat dengan jumlah koefesien regresi variabel pelayanan pajak sebayak 0,184 nilai $t$ hitung sebanyak $2.364>t$ tabel 1.65251 dengan tingkat signifikansi 0,019 $<0,05$.

3) Pengetahuan perpajakan berpengaruh terhadap kepatuhan wajib pajak di Kecamatan Suralaga (Desa Tebaban, Desa Dasan Borok, dan Desa Paok Lombok) hal ini dilihat dengan jumlah koefesien regresi variabel pengetahuan perpajakan sebanyak 0,124 jumlah $\mathrm{t}$ hitung sebayak $1.839>\mathrm{t}$ tabel 1.65251 dengan tingkat signifikansi 0,067>0,05.

4) Penegakan hukum pajak tidak berpengaruh pada kepatuhan wajib pajak di Kecamatan Suralaga (Desa Tebaban, Desa Dasan Borok, dan Desa Paok Lombok). Hal ini ditunjukkan dengan nilai koefesien regresi variabel penegakan hukum pajak 0,037 . jumlah $\mathrm{t}$ hitung sebayak $0,577<\mathrm{t}$ tabel 1.65251 dengan tingkat signifikansi $0,564>0,05$.

5) Secara simultan ada pengaruh antara (pendapatan, pelayanan pajak, pengetahuan perpajakan, dan penegakan hukum pajak terhadap kepatuhan wajib pajak) karna nilai $\mathrm{F}$ hitung berdasarkan uji statistik lebih tinggi dari F tabel $(3.540>2.41)$ karna jumlah signifikansi lebih rendah dari $0,05(0,008<0,05)$.

\section{Keterbatasan Penelitian}

Dalam penelitian ini tentunya penulis sadar bahwa masih ada kekurangan dan keterbatasan yang mengurangi kesempurnaan dari penelitian ini adapun kekurangan tersebut diantaranya:

1) Observasi ini di hasilkan dari memakai instrumen kuisioner yang berfundamen pada pemahaman jawaban responden. Hal ini bisa mengakibatkan kejaadian pada pemahaman responden berbeda dengan kenyataan yang ada dan mempunyai unsur subjektif dan jawaban yang tidak sesuai.

2) Peneliti ini tidak menimbangkan variabelvariabel lain yang kemungkin bisa mempengaruhi kepatuhan wajib pajak dalam membeyar pajak bumi dan bangunan di Kecamatan Suralaga.

\section{SARAN}

Dari kesimpulan diatas, maka masukanmasukan yang bisa diberikan tentang pendapatan, pelayanan pajak, pengetahuan perpjakan, dan penegakan hukum pajak pada kepatuhan wajib pajakadalah sebagai berikut:

1) Peneliti berikutnya diharapkan bisa menambah cara wawancara, supaya penulis bisa membicarakan pokok-pokok penting dari observasi tersebut dengan langsung pada responden agar tidak salah perkiraan dalam mengasih awaban.

2) Peneliti berikutnya diharapkan menambah jumlah variabel yang sedang menjadi penomena yang bisa mempengaruhi kepatuhan wajib pajak dalam melunasi pajak bumi dan bangunan di Kecamatan Suralaga, sebagai masukan memakai variabel pajak terutang, nilai jual objek tidak kena pajak (NJOPTKA) 


\section{DAFTAR PUSTAKA}

Adi, Titis, Wahyu. 2018. Pengaruh Kepatuhan Perpajakan Sanksi Dan Kesadaran Wajib Pajak Terhadap Kepatuhan Wajib Pajak Badan Pada Kpp Pratama. Skripsi. Cilacap: FE UIN Yogyakarta.

Adinda, Amelya. 2015. Pengaruh Kesadaran Membayar Pajak, Pemahaman Tentang Pajak, Sanksi Pajak Dan Kualitas Pelayanan Pajak Terhadap Kepatuhan Wajib Pajak: Stadi Pada Kantor Pelayanan Pajak Pratama Tampan Pekanbaru. Jurnal FEKON VOL. 2 No.2 Okt 2015.

Ananda. 2015. Faktor-Faktor Yang Mempengaruhi Kepatuhan Wajib Pajak Dalam Membayar Pajak Bumi Dan Bangunan Dengan Pendapatan Masyarakat Sebagai Variabel Moderating Di Kota Medan. Tesis. Medan: FEB Universitas Sumatera Utara.

Asgar, Satria, Budiman. 2019. Pengaruh Tingkat Pemahaman Peraturan Pajak Untuk Wajib Pajak Dan Kualitas Pelayanan Fiskus Terhadap Tingkat Kepatuhan Wajib Pajak: Studi Pada KP2KP Lombok Timur. Skripsi. Selong: FE Universitas Gunung Rinjani.

Asriyani, Yennita. 2014. Factor-Faktor Yang Mempengaruhi Kepatuhan Wajib Pajak Dalam Membayar Pajak Bumi Dan Bangunan(Artikel).

(https://media.neliti.com) Diakses 1 Januari 2014.

Ayu. 2019. Pengertian pajak jenis fungsi dan manfaatnya(artikel). (https://ukirama.com) diakses 16 Januari 2019.

Faizah, Siti. 2009. Faktor-Faktor Yang Mempengaruhi Kepatuhan Wajib Pajak Dalam Membayar Pajak Bumi Dan Bangunan Dikecamatan Dukuhturi Kabupaten Tegal. Skripsi. Semarang: FE UNNES.

Hardianti, Uci, Silvia. 2019. Masalah Penegakan Hukum Pajak (Artikel). (https://serambijambi.id). Diakses 9 Mei 2019.
Hasani, Ikhwan. 2019. Pengaruh Kesadaran Wajib Pajak Dan Pelayanan Pegawai Pajak Terhadap Kepatuhan Wajib Pajak Pada (KP2KP) Selong Kabupaten Lombok Timur. Skripsi. Selong: FE Universitas Gunung Rinjani.

Hestanto. 2018. Pengaruh Kualitas Pelayanan Terhadap Kepatuhan Wajib Pajak (Artikel). (https://www.hestanto.web.id). Diakses 15 Maret 2018

Khoiroh, Nahwatul. 2017. Pengaruh Sanksi, Sosialisasi, Dan Pendapatan Wajib Pajak Terhadap Kepatuhan Wajib Pajak Dalam Membayar Pajak Bumi Dan Bangunan Di Desa Gandaria. Skripsi. Jakarta: FAKULTAS ILMU TARBIYAH DAN KEGURUAN Universitas Islam Negeri Ayarif Hidayatullah.

Manullang, Ida. 2008. Pengaruh Kualitas Pelayanan Terhadap Kepuasan Pelanggan Jasa Penerbangan PT.Garuda Indonesia Airlines Di Bandara Polonia Medan.Tesis. Medan: Sp Universitas Sumatera Utara.

Nigar. 2020. Pegawai Pajak Yang Biasa Memungut Pajak Bumi Dan Bangunan Di Kecamatan Suralaga.

Prabowo, Yudiyanto. 2004. Akuntansi Perpajakan Terapan (Edisi Revisi). Jakarta: PT. Grasindo.

Resmi, Siti. 2011. PerpajakanTeori Dan Kasus (Edisi 6 Buku Pertama). Jakarta: Salemba Empat.

Sugiyono. 2014. Metode Penelitian Kuantitatif Kualitatif Dan $R$ dan D. Bandung: alfabeta.

Rakhmad, Basuki. 2015. Mengapa Kita Tidak Patuh Pajak (Majalah Pajak). (https://majalahpajak.net). Diakses $9 \mathrm{Mei}$ 2015.

Zafrullah, Muhammad. 2017. Penerapan Sanksi Administrasi Bagi Wajib Pajak Bumi Dan Bangunan Di Kabupaten Takalar. Makasar: FH Universitas Hasanuddin. 